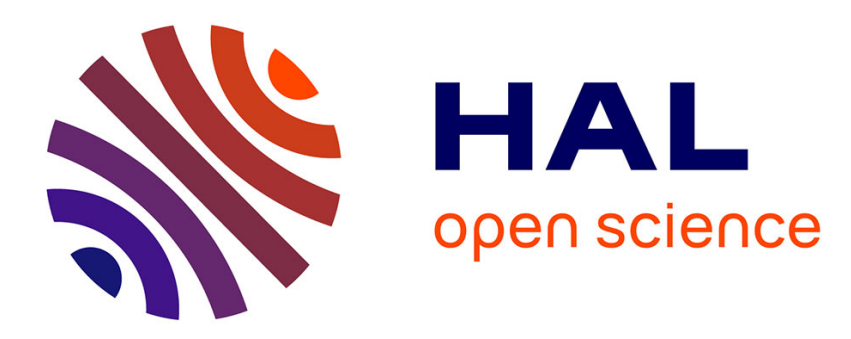

\title{
Synthesis of highly porous alumina-based materials
}

Pierre Alphonse, Benjamin Faure

\section{To cite this version:}

Pierre Alphonse, Benjamin Faure. Synthesis of highly porous alumina-based materials. Microporous and Mesoporous Materials, 2013, vol. 181, pp. 23-28. 10.1016/j.micromeso.2013.07.012 . hal01218619

\section{HAL Id: hal-01218619 \\ https://hal.science/hal-01218619}

Submitted on 21 Oct 2015

HAL is a multi-disciplinary open access archive for the deposit and dissemination of scientific research documents, whether they are published or not. The documents may come from teaching and research institutions in France or abroad, or from public or private research centers.
L'archive ouverte pluridisciplinaire HAL, est destinée au dépôt et à la diffusion de documents scientifiques de niveau recherche, publiés ou non, émanant des établissements d'enseignement et de recherche français ou étrangers, des laboratoires publics ou privés. 


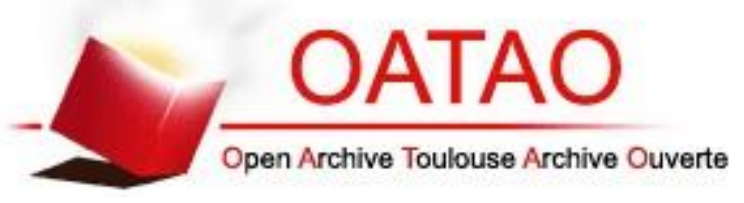

\section{Open Archive Toulouse Archive Ouverte (OATAO)}

OATAO is an open access repository that collects the work of Toulouse researchers and makes it freely available over the web where possible.

This is an author-deposited version published in: http://oatao.univ-toulouse.fr/ Eprints ID: 13995

To link to this article : DOI:10.1016/j.micromeso.2013.07.012

URL : http://dx.doi.org/10.1016/j.micromeso.2013.07.012

\section{To cite this version:}

Alphonse, Pierre and Faure, Benjamin Synthesis of highly porous alumina-based materials. (2013) Microporous and Mesoporous Materials, vol. 181. pp. 23-28. ISSN 1387-1811

Any correspondence concerning this service should be sent to the repository administrator: staff-oatao@ listes.diff.inp-toulouse.fr 


\title{
Synthesis of highly porous alumina-based materials
}

\author{
Pierre Alphonse*, Benjamin Faure \\ CIRIMAT-UPS, Université de Toulouse, 118 route de Narbonne 31062, Toulouse cedex 09, France
}

Keywords:

Pluronics $^{\circledR}$

Boehmite

$\gamma$-Alumina

Mesoporous oxide

\begin{abstract}
A B S T R A C T
$\gamma$-Alumina-based materials with high porous volume, tunable pore size, were synthesized by the addition of both PEO/PPO/PEO triblock copolymers (Pluronics ${ }^{\circledR} \mathrm{F} 127$ and P123) and metal nitrates $\left(\mathrm{Al}^{3+}, \mathrm{Mn}^{2+}\right.$, $\mathrm{Cu}^{2+}$ ) in a boehmite $(\mathrm{AlOOH})$ nanoparticle hydrosol. During the subsequent thermal treatment, the surfactant was removed leaving a highly porous framework.

The pore size distribution was strongly dependent on the metal nitrate added and its concentration. By this simple process it was possible to modify the porous volume in the range $0.3-2.6 \mathrm{~cm}^{3} \mathrm{~g}^{-1}$ and the median pore diameter in the range $5-40 \mathrm{~nm}$. All these materials presented high surface areas in the range $300-500 \mathrm{~m}^{2} \mathrm{~g}^{-1}$.

During the drying $\mathrm{AlOOH}$ particles aggregate to form linear objects (flat rods, laths) in order to minimize electrostatic repulsion. We think that the improvement of the textural characteristics of $\gamma$-alumina could be explained by the adsorption of copolymer onto these fiber-like objects, preventing the compact rearrangement of the boehmite nanoparticles in a compact "card-pack" microstructure during the drying.

The addition of electrolytes induces a reduction of electrostatic repulsions, leading to the formation of both fiber-like objects at lower AlOOH concentration, and a 3D network by bridging these 1D objects. This bridging is reversible since the gel returns to a sol state under shearing, but polymer adsorption can prevent the full collapsing of this network during the drying step and a huge porosity can be maintained after calcination.
\end{abstract}

\section{Introduction}

Synthesis of transition alumina with controlled surface area and pore size has been the subject of intensive academic and industrial research because these materials have a wide range of potential applications such as catalysis, adsorption, separation and energy storage [1].

Mesoporous alumina (MA) may be prepared by the supramolecular template mechanism [2-5] where simultaneous condensation of metal ions and self-assembly of surfactant molecules forms a hybrid organic-inorganic mesophase. However a very simple procedure, "the nanoparticle route" [6-10], which consists in introducing a nonionic surfactant in a pre-synthesized colloidal sol can also gives non ordered mesoporous $\gamma$-alumina with large surface area, large pore volume, tunable pore size distribution over a wide range of pore size and an excellent thermal stability. Besides the nanoparticle route conducted in aqueous medium has the advantage of producing colloidal sols with controlled viscosity and high stability (i.e. against precipitation or phase separation), which would be of interest for a large-scale production of coatings.

\footnotetext{
* Corresponding author. Tel.: +33 561556285.

E-mail addresses: alphonse@chimie.ups-tlse.fr (P. Alphonse), faure@chimie.upstlse.fr (B. Faure).
}

In previous works using the nanoparticle route, the surface area and the pore size distribution (PSD) were modified through the choice of the boehmite precursor, the surfactant, the ratio surfactant/AlOOH and the addition of hydrocarbons.

The main goal of this work is to report the effect, on the textural characteristics of mesoporous $\gamma-\mathrm{Al}_{2} \mathrm{O}_{3}$, of the addition of a metal nitrate in a boehmite hydrosol containing hydrophilic non-ionic surfactants, Pluronic ${ }^{\circledR}$ F127 and Pluronic ${ }^{\circledR}$ P123. These materials are ABA type triblock copolymers of ethylene oxide (EO) and propylene oxide (PO). F127 corresponds to $\mathrm{EO}_{100} \mathrm{PO}_{65} \mathrm{EO}_{100}$ with $\mathrm{MW}=12,600$, whereas $\mathrm{P} 123$ corresponds to $\mathrm{EO}_{19} \mathrm{PO}_{69} \mathrm{EO}_{19}$ with $\mathrm{MW}=5750$ [11]. To the best of our knowledge, it is the first time that the remarkable enhancement of $\gamma$-alumina porosity induced by the addition of metallic salts together with triblock copolymer is pointed out.

\section{Experimental}

\subsection{Synthesis of boehmite sols}

Boehmite sols were synthesized according to the method reported by Yoldas [12-14]. In a typical procedure, $185 \mathrm{~mL}$ of hot water $\left(85^{\circ} \mathrm{C}\right)$ were added very fast, under vigorous stirring, to $25.3 \mathrm{~g}(0.1 \mathrm{~mol})$ of aluminum tri-sec-butoxide $(\mathrm{ASB})\left[\mathrm{Al}\left(\mathrm{OC}\left(\mathrm{CH}_{3}\right)_{3}\right)_{3}\right.$, 
Acros Organics]. The hydrolysis ratio, $\mathrm{h}=\left[\mathrm{H}_{2} \mathrm{O}\right] /[\mathrm{Al}] \approx 100$. After $15 \mathrm{~min}$, the white precipitate was peptized by adding $0.474 \mathrm{~mL}$ $(0.1 \mathrm{~mol})$ of nitric acid $\left(\mathrm{HNO}_{3}, 68 \%\right.$, Fluka $)\left(\left[\mathrm{HNO}_{3}\right] /[\mathrm{Al}]=0.07\right)$. The mixture was stirred and maintained at $85^{\circ} \mathrm{C}$ for $24 \mathrm{~h}$; the white suspension changed gradually to a transparent sol. During the first $3 \mathrm{~h}$, the reaction flask was kept uncovered in order to allow the isobutanol formed during hydrolysis to evaporate. The concentration of aluminum in the final sol was about $0.8 \mathrm{~mol} \mathrm{~L}^{-1}$ with a $\mathrm{pH}$ in the range 4.5-5.3. Increasing the time during which the reaction flask was kept uncovered allows preparing more concentrated sols.

Additives like Pluronic ${ }^{\circledR}$ F127 (Sigma), Pluronic ${ }^{\circledR}$ P123 (Sigma), aluminum nitrate $\left[\mathrm{Al}\left(\mathrm{NO}_{3}\right)_{3}, 9 \mathrm{H}_{2} \mathrm{O}\right.$, Alfa Aesar] manganese nitrate $\left[\mathrm{Mn}\left(\mathrm{NO}_{3}\right)_{2}, 6 \mathrm{H}_{2} \mathrm{O}\right.$, Alfa Aesar] or copper nitrate $\left[\mathrm{Cu}\left(\mathrm{NO}_{3}\right)_{2}, 4 \mathrm{H}_{2} \mathrm{O}\right.$, Alfa Aesar] were added in the sol and the mixture was kept under gentle stirring for $24 \mathrm{~h}$ at room temperature. The transparency of the boehmite sols was not changed after addition of copolymer or metal nitrate, only the color was affected in the case of copper nitrate addition (the sols turned light blue).

Xerogels were made by drying the sols in PTFE plates at $70^{\circ} \mathrm{C}$ for $12 \mathrm{~h}$. This gave a glassy material which was fired in air at $500{ }^{\circ} \mathrm{C}$ for $2 \mathrm{~h}$. The AlOOH concentration in the sols was determined by weight loss on ignition at $1000^{\circ} \mathrm{C}$ for $2 \mathrm{~h}$. The polymer amount is expressed by its weight/weight percent ( $w / w \%)$ concentration in the sol. The concentration of F127 ranged from 2\% to $12 \%$ and the concentration of P123 from $4 \%$ to $18 \%$. The metal amount is expressed by weight/weight percent $(\mathrm{w} / \mathrm{w} \%)$ concentration in the fired $\gamma$-alumina xerogel. Each metallic element concentration in xerogels was checked by ICP-AES analysis. The $\mathrm{Al}$ and $\mathrm{Cu}$ concentrations ranged from $1 \%$ to $6 \%$ and the Mn concentration from $1 \%$ to $7 \%$.

\subsection{Rheology}

Rheology measurements on the sols were performed with a Physica Anton Paar (MCR-300) controlled stress rheometer, using cone-plate geometry. The dimensions of the geometry were $50 \mathrm{~mm}$ for the diameter and $1^{\circ}$ for the angle. The minimum distance between the plate and truncated cone was $0.05 \mathrm{~mm}$. Rheograms were recorded at $20^{\circ} \mathrm{C}$, over a range $1-1000 \mathrm{~s}^{-1}$, with a total time period of $300 \mathrm{~s}$ for both the increasing- and decreasing-shear-rate sweeps.

\subsection{Powder X-ray diffraction (PXRD)}

The crystal structure was investigated by powder X-ray diffraction. Data was collected, at room temperature, with a Bruker AXS D4 $\theta-2 \theta$ diffractometer, in the Bragg-Brentano geometry, using filtered $\mathrm{Cu} \mathrm{K \alpha}$ radiation and a graphite secondary-beam monochromator. Diffraction intensities were measured by scanning from $20^{\circ}$ to $80^{\circ}(2 \theta)$ with a step size of $0.02^{\circ}(2 \theta)$. A quantitative estimate of the cell parameters and peak broadening was accomplished by profile fitting of the whole XRD patterns. We used the Fityk software [15]. The peak profiles were modeled by pseudo-

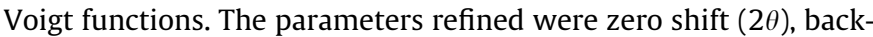
ground, unit cell parameters and peak shapes. The refined FWHM (full-width at half-maximum) of the lines was used to compute, by the Scherrer's equation, the average crystallite size [16]. The instrumental broadening contribution was evaluated by using $\alpha$ alumina sample as standard.

\subsection{Specific surface area, pore size distribution}

Specific surface area and pore size distribution were calculated from nitrogen adsorption-desorption isotherms collected at $77 \mathrm{~K}$, using an adsorption analyzer Micromeritics Tristar II 3020. The specific surface areas were computed from adsorption isotherms, using the Brunauer-Emmett-Teller (BET) method [17]. The pore size distributions (PSD) were computed from desorption isotherms by the NLDFT method [18] (with Quantachrome Autosorb-1 software using silica equilibrium transition kernel at $77 \mathrm{~K}$, based on a cylindrical pore model).

Pore volume $\left(P_{\mathrm{v}}\right)$ was calculated from the adsorbed volume $\left(V_{\mathrm{a}}\right)$ at a relative pressure of $0.995 \mathrm{by}$ :

$P_{v}=\frac{N_{2} \text { gas density }}{N_{2} \text { liq density }} V_{a}=0.00155 V_{a}$

The relative errors associated with adsorption-desorption analysis were estimated to be the followings: $S_{\mathrm{BET}}, 5 \% ; P_{\mathrm{v}}, 5 \%$. Prior to analysis the samples $(0.02-0.1 \mathrm{~g})$ were degassed at $350^{\circ} \mathrm{C}$ overnight $(\approx 15 \mathrm{~h})$ to remove the species adsorbed on the surface.

\subsection{Scanning electron microscopy}

Scanning electron microscopy analyses were performed, with a SEM FEG JEOL JSM-6700F, on small pieces cut from coated substrates. Before analysis the samples were covered with a thin layer $(5 \mathrm{~nm})$ of Pt by sputter coating.

\section{Results}

\subsection{Rheology}

Fig. 1 shows the effect of some additives on the rheological behavior of the boehmite sols. Full symbols correspond to increasing shear-rate whereas open symbols relate to decreasing shearrate. Without additives the sol had a low viscosity. It had an almost Newtonian behavior although a slight decrease of viscosity was observed with increasing shear rate. Addition of P123 (17 wt\%) increased 4 times the viscosity. Like for the sol without additives the behavior was close to Newtonian with just a slight shear thinning. Addition of P123 and Mn nitrate (5 wt\%) had a striking effect, the viscosity at low shear rate $\left(1 \mathrm{~s}^{-1}\right)$ increased more than 500 times. However the viscosity strongly decreased with rising shear rate. Moreover a thixotropic behavior was observed, because the viscosities for decreasing shear rate were lower than the values recorded for increasing shear rate. The sols containing Mn nitrate
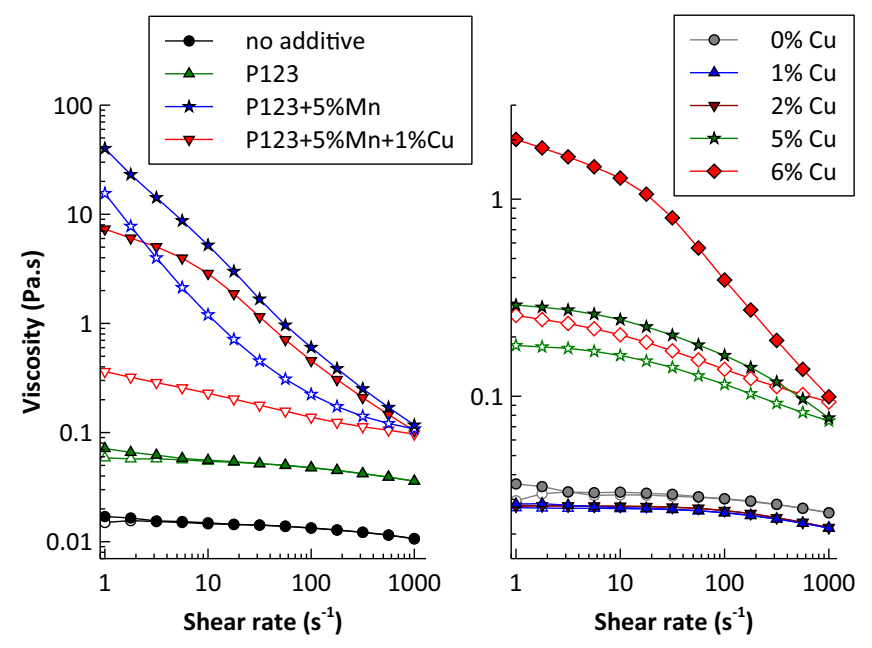

Fig. 1. Viscosity vs shear rate curves, recorded at $20^{\circ} \mathrm{C}$, with boehmite sols containing various additives. Full symbols correspond to increasing shear-rate whereas open symbols relate to decreasing shear-rate. The left graph shows the change in viscosity induced by addition of increasing amount of $\mathrm{Cu}$ nitrate in boehmite sol containing P123. P123 concentration was always $17 \mathrm{wt} \%$. 
gelled quickly as soon as shearing was stopped. The formation of such a gel results from the attractive interactions between particles leading to the formation of 3D network. Under shear, the structure of this gel breaks-down and the viscosity decreases. On standing, the network builds-up and viscosity increases. The thixotropic behavior is observed because building the network takes more time than destroying it.

Gelation of a boehmite sol, induced by the addition of electrolytes, has already been reported [19-22]. The boehmite sols are stabilized by electrostatic repulsion. According to the DLVO theory [23] an electrostatic double layer surrounds each particle. The thickness of the diffuse part of the double layer is inversely proportional to the square root of the ionic strength of the solution. Addition of electrolytes increases the ionic strength and therefore reduces the repulsion between particles leading to gel formation.

Addition of $\mathrm{Cu}$ nitrate (1\%) to the sol containing both P123 and Mn nitrate provoked a significant lowering (more than $5 \times$ ) of the viscosity at low shear rate. However the shear thinning behavior below $10 \mathrm{~s}^{-1}$ was less marked so that the viscosity at $1000 \mathrm{~s}^{-1}$ was almost the same that without $\mathrm{Cu}$ nitrate addition. Moreover the sol with $\mathrm{Cu}$ nitrate was less viscous but more thixotropic. It is interesting to remark that addition of $\mathrm{Cu}$ nitrate (1\% and $2 \%$ ) to a sol containing only P123 slightly decreased the viscosity (about $15 \%)$.

\section{2. $X R D$}

\subsubsection{Interaction between copolymer and $\mathrm{AlOOH}$}

A comparison between XRD patterns of $\mathrm{AlOOH}$ xerogels containing increasing amount of F127 are shown on Fig. 2. The pattern of F127 has also been plotted. The boehmite structure corresponds to an orthorhombic unit cell with the space group $\mathrm{Cmcm}$. The broad diffraction lines show that the crystallites are nanosized. Whole profile fitting of the pattern revealed the crystallite anisotropy because the widths of the $\left(\begin{array}{lll}0 & 0 & 2\end{array}\right)$ and $\left(\begin{array}{lll}2 & 0 & 0\end{array}\right)$ reflections were smaller than the others. The refinement was done using a separate set of parameters (peak intensity, FWHM, Lorentzian fraction of pseudo-Voigt function) for modeling each diffraction line. The peak positions were determined by the cell parameters except for the first line (0 20 ), which was fitted separately because it presented too large a shift toward small angles from its calculated position. The refined FWHM of the ( $\left(\begin{array}{lll}2 & 0 & 0\end{array}\right),\left(\begin{array}{lll}0 & 2 & 0\end{array}\right)$ and $\left(\begin{array}{lll}0 & 0 & 2\end{array}\right)$ lines were used to estimate, by Scherrer's equation, the average crystallite size along the $a$-, $b$ - and $c$-axis. The crystallite dimensions along $a$ and

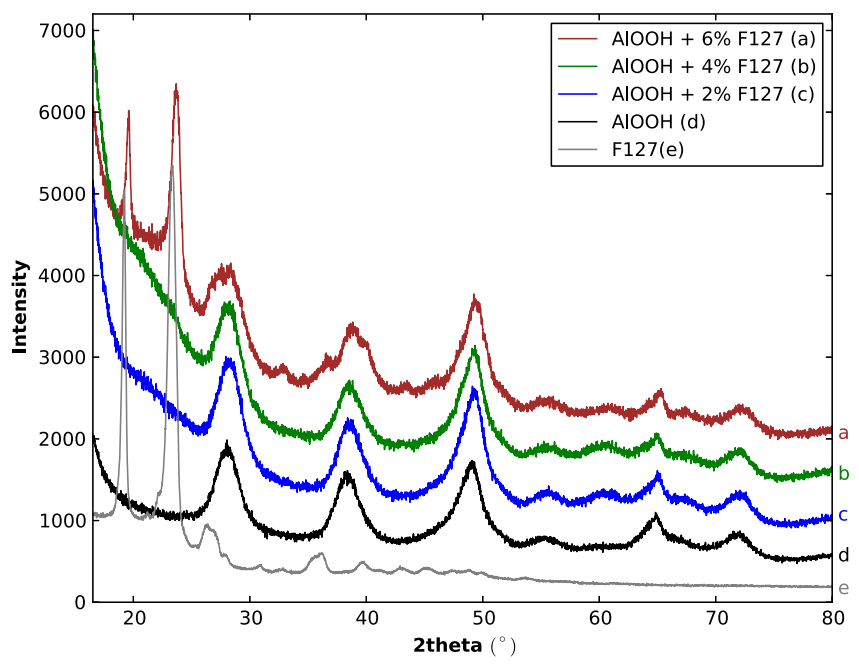

Fig. 2. Comparison between XRD patterns of dried boehmite xerogels containing increasing amount of F127. The pattern of pure F127 is also plotted (e). $c$ axes are larger than that along the $b$ axis, which means that the crystallites are in the shape of platelets or disks. The thickness was in the range $2.5-3 \mathrm{~nm}$; the length (along the $c$ axis) was in the range $5-6 \mathrm{~nm}$ and the width was in the range $7-8 \mathrm{~nm}$.

The pattern of F127 (pattern e) shows two main sharp peaks at $2 \theta=19.2$ and $23.4^{\circ}$. They correspond to $\left(\begin{array}{lll}1 & 2 & 0\end{array}\right)$ and $\left(\begin{array}{llll}0 & 1 & 4\end{array}\right)$ reflections of the crystalline phase formed by the PEO fragments [24]. For xerogels prepared from sols containing 2-4 wt\% of F127 (patterns $b$ and $c$ ) these peaks were not observed. It should be emphasized that for a concentration of $4 \mathrm{wt} \%$, the mass of $\mathrm{F} 127$ is equivalent to the mass of $\mathrm{AlOOH}$. These lines were only present for $6 \mathrm{wt} \%$ of F127 (pattern $a$ ). However they were broader than those of F127 and they were also shifted to higher angle $\left(+0.3^{\circ}\right)$. Therefore the interaction between $\mathrm{AlOOH}$ surface and the PEO blocks of the copolymer was strong enough to prevent its crystallization as long as the polymer amount was not exceeding the boehmite mass.

P123 having a lower proportion of PEO did not give the sharp diffraction lines observed with F127 so that the interaction with $\mathrm{AlOOH}$ was less easy to evidence from the XRD patterns.

\subsubsection{Effect of copolymer and metallic additives on crystal structure of $\gamma$-alumina}

XRD diffraction patterns of $\gamma$-alumina prepared without copolymer or with F127 or P123 addition were very similar. Pattern matching revealed that the addition of copolymers provoked a decrease of the ordering domains of the $(222)$ reflection (scattering from the oxygen sublattice [25]). Fig. 3 shows that $\mathrm{Mn}$ and $\mathrm{Cu}$ nitrate addition induced a linear increase in the cell parameter of $\gamma$-alumina. This indicates that $\mathrm{Mn}^{2+}$ or $\mathrm{Cu}^{2+}$ ions did not remain at the surface of alumina crystallites but diffused into the bulk to give a solid solution.

\section{3. $\mathrm{N}_{2}$-adsorption}

\subsubsection{Effect of copolymer concentration}

The effect of F127 addition on surface area and pore size distribution has already been reported [10]. In this work we studied the effect of the P123 content on the textural characteristics. In Fig. 4 the BET surface area $\left(S_{\mathrm{BET}}\right)$ and the pore volume $\left(P_{\mathrm{v}}\right)$ of xerogels prepared with copolymers are plotted against the polymer

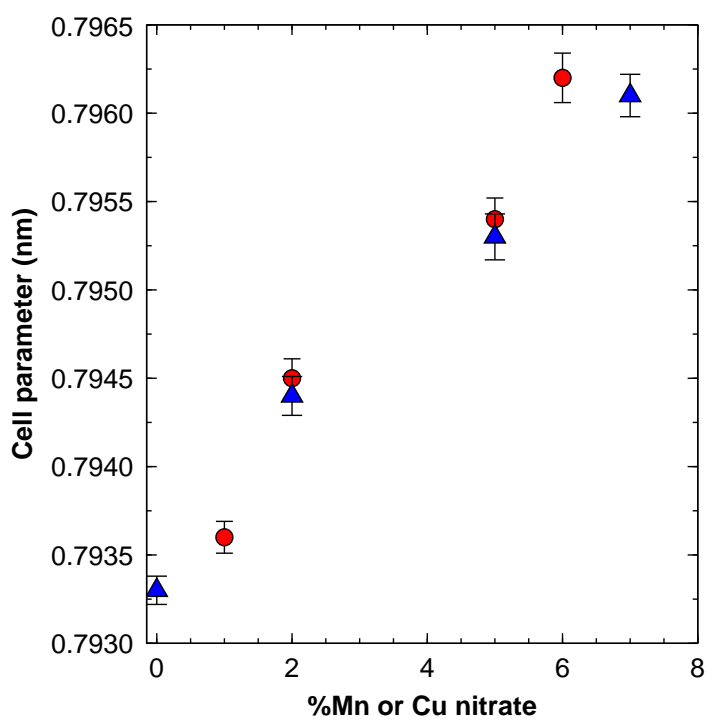

Fig. 3. Effect of addition of $\mathrm{Mn}$ or $\mathrm{Cu}$ nitrate on the cell parameter of $\gamma$-alumina xerogels (after calcination at $500{ }^{\circ} \mathrm{C}$ for $2 \mathrm{~h}$ ). The metal amount is expressed by weight/weight percent $(\mathrm{w} / \mathrm{w} \%)$ concentration in the fired xerogel. 

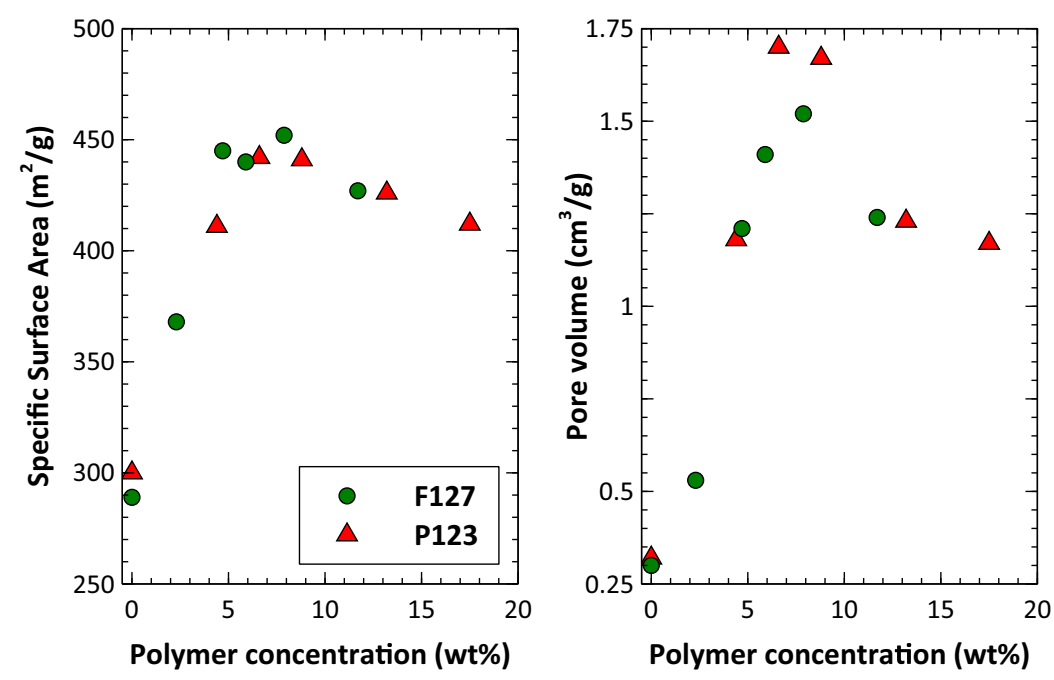

Fig. 4. Effect of copolymer concentration on BET surface area (left) and pore volume (right) of $\gamma$-alumina xerogels (after calcination at $500{ }^{\circ} \mathrm{C}$ for $2 \mathrm{~h}$ ). The polymer amount is expressed by its weight/weight percent (w/w\%) concentration in the sol. The data for F127 are from Ref. [10].

concentration. Both copolymers gave very similar $S_{\mathrm{BET}}$ (left plot); the surface area increased quickly up to a maximum in the range $5-10 \%$; then increasing the polymer amount gradually decreased $S_{\mathrm{BET}}$.

For $P_{\mathrm{v}}$ (right plot) a marked increase was observed up to $7-8 \%$. Then in the range $8-12 \%$ the pore volume decreased quickly. For larger content it did not change anymore. Though the trend was similar for both copolymers, P123 gave higher $P_{\mathrm{v}}$ at the optimum (1.7 instead of $1.5 \mathrm{~cm}^{3} \mathrm{~g}^{-1}$ ). This corresponds to an expansion of more than 6 times of the pore volume without additive. For $\mathrm{P} 123$, the volume of the polymer at the maximum was $0.65 \mathrm{~cm}^{3}$ $\mathrm{g}^{-1}$ thus the copolymer created more than twice as much pore volume than its own volume.

\subsubsection{Effect of addition of metal nitrates}

The BET surface area $\left(S_{\mathrm{BET}}\right)$ and pore volume $\left(P_{\mathrm{v}}\right)$ of xerogels prepared from sols containing $\mathrm{P} 123$ and $\mathrm{Al}, \mathrm{Mn}$ and $\mathrm{Cu}$ nitrates are reported in Table 1 . The cumulative surface area $\left(S_{\text {cum }}\right)$ and the cumulative pore volume $\left(V_{\text {cum }}\right)$ calculated by NLDFT are also given. A good agreement between $V_{\text {pore }}$ and $V_{\text {cum }}$ was observed

\section{Table 1}

Surface area and porosity of $\gamma$-alumina xerogels prepared with addition of both P123 and metal nitrate, after calcination at $500{ }^{\circ} \mathrm{C}$ for $2 \mathrm{~h}$. The polymer amount is expressed by its weight/weight percent $(\mathrm{w} / \mathrm{w} \%)$ concentration in the sol. The metal amount is expressed by weight/weight percent $\left(\mathrm{w} / \mathrm{w} \%\right.$ ) concentration in the fired xerogel. $S_{\mathrm{BET}}$ is BET specific surface area; $V_{\text {pore }}$ is the adsorbed volume at $P / P_{0}=0.995$. $S_{\text {cum }}$ is the cumulative surface area calculated by NLDFT; $V_{\text {cum }}$ is the pore volume calculated by NLDFT.

\begin{tabular}{cllllll}
\hline$\%$ P123 & Nitrate & $\% \mathrm{M}$ & $S_{\text {BET }}$ & $V_{\text {pore }}$ & $S_{\text {cum }}$ & $V_{\text {cum }}$ \\
\hline 17 & None & 0 & 405 & 1.55 & 427 & 1.51 \\
17 & $\mathrm{Cu}$ & 1 & 404 & 1.64 & 426 & 1.60 \\
17 & $\mathrm{Cu}$ & 2 & 406 & 1.88 & 442 & 1.84 \\
17 & $\mathrm{Cu}$ & 5 & 403 & 2.04 & 439 & 1.99 \\
17 & $\mathrm{Cu}$ & 6 & 391 & 1.96 & 420 & 1.90 \\
17 & $\mathrm{None}$ & 0 & 387 & 1.53 & 416 & 1.47 \\
17 & $\mathrm{Al}$ & 1 & 388 & 2.06 & 409 & 2.04 \\
17 & $\mathrm{Al}$ & 2 & 404 & 2.22 & 416 & 2.20 \\
17 & $\mathrm{Al}$ & 3 & 374 & 2.37 & 365 & 2.32 \\
17 & $\mathrm{Al}$ & 4 & 354 & 2.63 & 358 & 2.59 \\
17 & $\mathrm{Al}$ & 5 & 382 & 2.10 & 363 & 2.06 \\
17 & $\mathrm{Al}$ & 6 & 380 & 1.88 & 367 & 1.76 \\
17 & $\mathrm{Mn}$ & 1 & 413 & 1.76 & 456 & 1.73 \\
17 & $\mathrm{Mn}$ & 2 & 431 & 1.94 & 477 & 1.90 \\
17 & $\mathrm{Mn}$ & 5 & 380 & 1.73 & 411 & 1.61 \\
17 & $\mathrm{Mn}$ & 6 & 398 & 1.78 & 423 & 1.75 \\
17 & $\mathrm{Mn}$ & 7 & 391 & 1.79 & 406 & 1.76 \\
17 & $\mathrm{Mn}+\mathrm{Cu}$ & $5+1$ & 501 & 2.62 & 537 & 2.56 \\
9 & $\mathrm{Mn}+\mathrm{Cu}$ & $5+1$ & 394 & 1.82 & 430 & 1.76 \\
\hline
\end{tabular}

which was expected as the calculated isotherm fitted closely the experimental one. Most often $S_{\text {cum }}$ was slightly above $S_{\mathrm{BET}}$, however this difference was not considered significant.

The addition of a metal nitrate did not produce an important effect on $S_{\mathrm{BET}}$ when the concentration of metal was low (below 3\%). For larger concentrations the surface area decreased slightly. Addition of a metal nitrate had a marked effect on the pore volume especially in the case of Al. For example, xerogels prepared with $4 \%$ of Al nitrate reached an outstanding pore volume of $2.6 \mathrm{~cm}^{3} \mathrm{~g}^{-1}$.

The last rows of the Table 1 show that the textural characteristics of a xerogel containing $5 \%$ Mn nitrate were strongly enhanced by addition of $1 \% \mathrm{Cu}$ nitrate. The surface area was increased by $25 \%$ and the pore volume expanded by almost $50 \%$. However this striking augmentation occurred only with a P123 concentration of $17 \%$ although the maximum observed without addition of metal nitrates was for a twice as lower concentration. At this copolymer concentration (9\%) only a minor expansion was found.

Some representative isotherms and their associated PSD, calculated using NLDFT method are plotted in Fig. 5. These isotherms were all of the same type IV with an H1 hysteresis loop [26]. Without polymer the PSD was narrow (width at half height of only $1 \mathrm{~nm}$ ) giving a maximum at $5 \mathrm{~nm}$. After addition of P123 the PSD was still monomodal but broader (width at half height of $4 \mathrm{~nm}$ ) and shifted toward larger pore size, with a maximum at $13 \mathrm{~nm}$. All the small mesopores, observed without P123, vanished. Addition of P123 $+5 \%$ Mn nitrate did not broaden the PSD however it was shifted toward larger pore size with a maximum at $17 \mathrm{~nm}$. Addition of $1 \% \mathrm{Cu}$ nitrate to this xerogel expanded the PSD (width at half height of $10 \mathrm{~nm}$ ) because it created a new family of pores at $23 \mathrm{~nm}$. The PSD of the xerogel prepared with addition of P123 + 4\% Al nitrate was bimodal with two very broad peaks at 25 and $40 \mathrm{~nm}$. Fig. 6 shows that Al nitrate addition always gave a bimodal PSD even for $1 \%$ Al. Increasing the Al nitrate concentration shifted the PSD towards larger pore size and broadens the distribution.

\subsection{Scanning electron microscopy}

The scanning electron microscopy image (Fig. 7b) of a xerogel prepared from the sol containing P123, 5\% Mn and 1\% Cu nitrate after calcination at $500{ }^{\circ} \mathrm{C}$ for $2 \mathrm{~h}$, confirms the very high porosity of this material (compared to a xerogel prepared without additives, Fig. 7a) and shows that the boehmite nanoparticle organize themselves in fiber-like objects. 


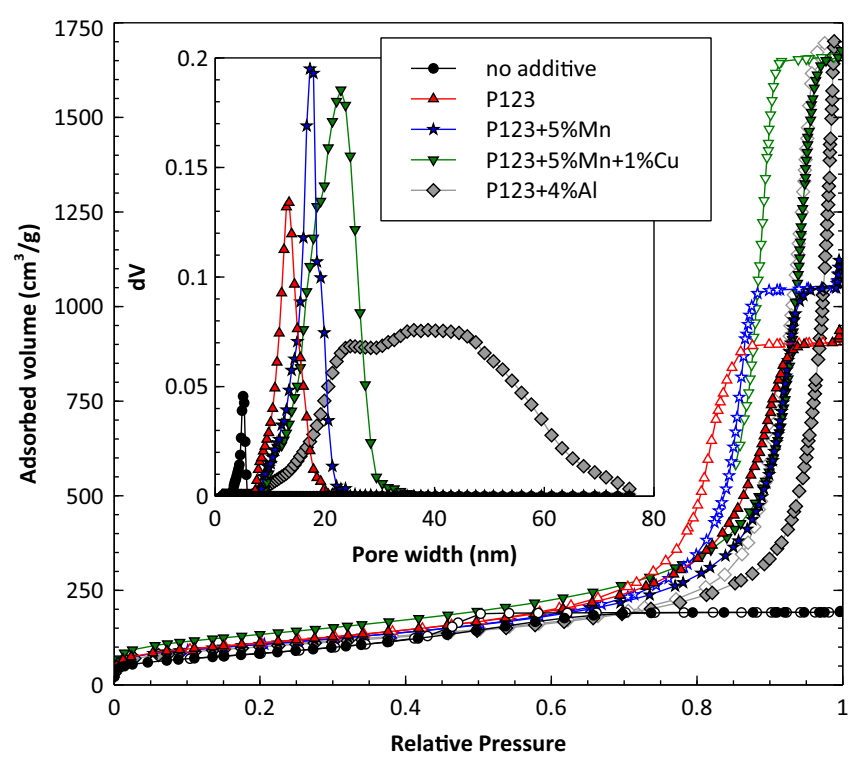

Fig. 5. Effect of addition of both $\mathrm{P} 123$ and metal nitrate on the adsorptiondesorption isotherms and PSD of $\gamma$-alumina xerogels (after calcination at $500{ }^{\circ} \mathrm{C}$ for $2 \mathrm{~h})$.

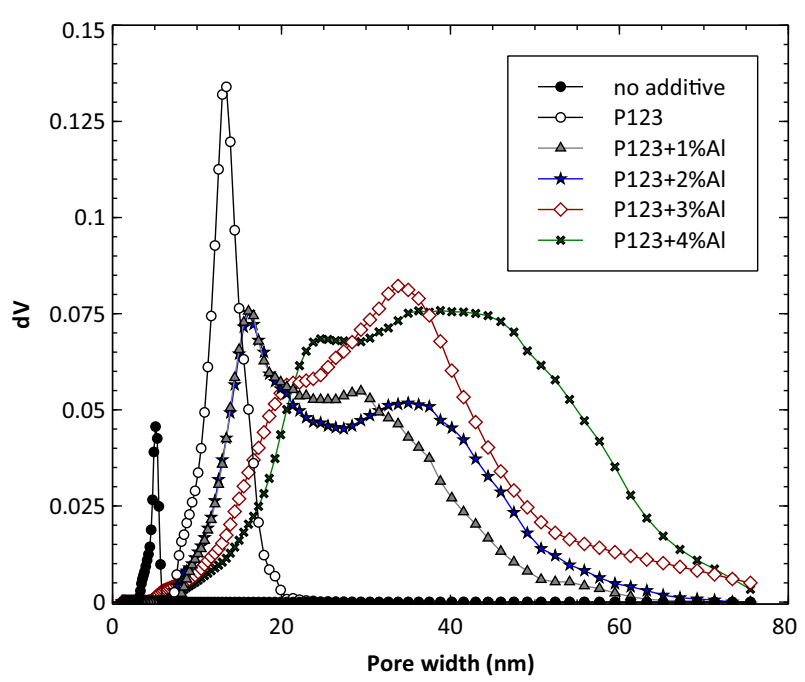

Fig. 6. Effect of addition of both P123 and aluminum nitrate on the PSD of $\gamma$ alumina xerogels (after calcination at $500{ }^{\circ} \mathrm{C}$ for $2 \mathrm{~h}$ ).

\section{Discussion}

Several mechanisms have been proposed to explain how the addition of nonionic polyethylene oxide (PEO) surfactants in a boehmite sol can generate a highly porous material. Zhu and coworkers [6], working under hydrothermal conditions $\left(100^{\circ} \mathrm{C}\right)$, proposed a surfactant-induced fiber formation (SIFF) mechanism in which the surfactant interact with the colloid particles of $\mathrm{AlOOH}$ through hydrogen bonding. This interaction directs the crystal growth of boehmite leading to fiber formation. During the subsequent heating, the surfactant volatilizes, leaving a highly porous framework while the boehmite was converted to $\gamma$-alumina, retaining the fiber morphology. Liu [7] and Zhang [8] assumed that the surfactant act as a scaffold to direct the stacking of boehmite particle leading to the formation of a mesoporous material. Jaroniec and co-workers [9] assumed the growth of a 3D boehmite-surfactant superstructure by agglomeration of spherical boehmite particles.

To the best of our knowledge, no investigation has been reported in the literature on the interactions between
PEO-PPO-PEO polymers and boehmite nanoparticles. The only study concerns the use of a polyol (xylitol) and indicates that xylitol interacts preferentially with lateral surfaces than with the basal (0 10 0) surface [27]. Anyway we can infer that, when copolymer is introduced in the boehmite sols, it interacts, probably through hydrogen bonding, with the surface of boehmite crystallites. Probably the copolymer should take the configuration in which the polyethylene oxide (PEO) groups lie on the nanoparticle surface whereas the polypropylene oxide (PPO) chains head away from the surface.

This interaction can be revealed by XRD:

(i) As we have seen above, for concentration of F127 in sol below 6\%, the interaction between $\mathrm{AlOOH}$ surface and the PEO blocks was strong enough to prevent its crystallization. For larger concentration the copolymer can crystallize but it is still affected by the interaction with $\mathrm{AlOOH}$ (giving smaller coherent domain size).

(ii) When polymer free boehmite sols are slowly dried in air, a transparent film is obtained. X-ray diffraction pattern of this film almost exclusively shows the (020) reflection. This indicates that most of the primary plate-like crystals align with their (020) axis normal to the film [28]. In contrast, for polymer containing xerogels (Fig. 2), all of the Bragg diffraction lines of a boehmite phase are observed [8]. Thus the boehmite crystallites cannot take their preferential orientation because the copolymer is adsorbed on their surface.

The PZC for boehmite reported in literature is close to 9 [2931]. The $\mathrm{pH}$ of our sols is in the range 4.5-5.0, thus the surface charge is high, leading to electrostatic repulsion between the particles. Under these conditions, particles aggregate to form linear objects (flat rods, laths) in order to minimize electrostatic repulsion. These kinds of objects can be clearly seen in the SEM image of a xerogel (Fig. 7). This is in agreement with the fact that the addition of P123 caused the total disappearance of the small mesopores that formed all the porosity in the polymer free xerogels (Fig. 5). These small pores resulted from voids between close packed crystallites, because their size was similar to the crystallite size. The disappearance of these small pores means that boehmite crystallites aggregate in larger objects so that porosity results only from the voids between these objects.

Thus the improvement of the textural characteristics of $\gamma$-alumina could be explained by the adsorption of copolymer onto these fiber-like objects, preventing the compact rearrangement of the boehmite nanoparticles in a compact "card-pack" microstructure during the drying. Besides we think that the formation of micelles could also account, at least for F127, for the pore expansion observed above $6 \%$ because, in a previous work [10], we showed that hydrocarbons could be solubilized within the hydrophobic core of the micelles that swelled, yielding further expansion of pore volume.

After addition of metal nitrates the boehmite sols gelled quickly. Using the same interpretation that Fukasawa and Tsujii [19], we assume that the reduction of electrostatic repulsions, due to the addition of electrolyte, leads to the formation of both fiber-like objects at lower $\mathrm{AlOOH}$ concentration, and a 3D network by bridging these $1 \mathrm{D}$ objects. The bridging is reversible since the gel returns to a sol state under shearing but polymer adsorption can prevent the full collapsing of this network during the drying step. It seems probable that the bridging will depend on the metallic cation, which could explain the large differences in PSD according to the nitrate added.

On the other hand the large expansion of the pore size could also be explained by an increase in size of the micelles. Indeed it 

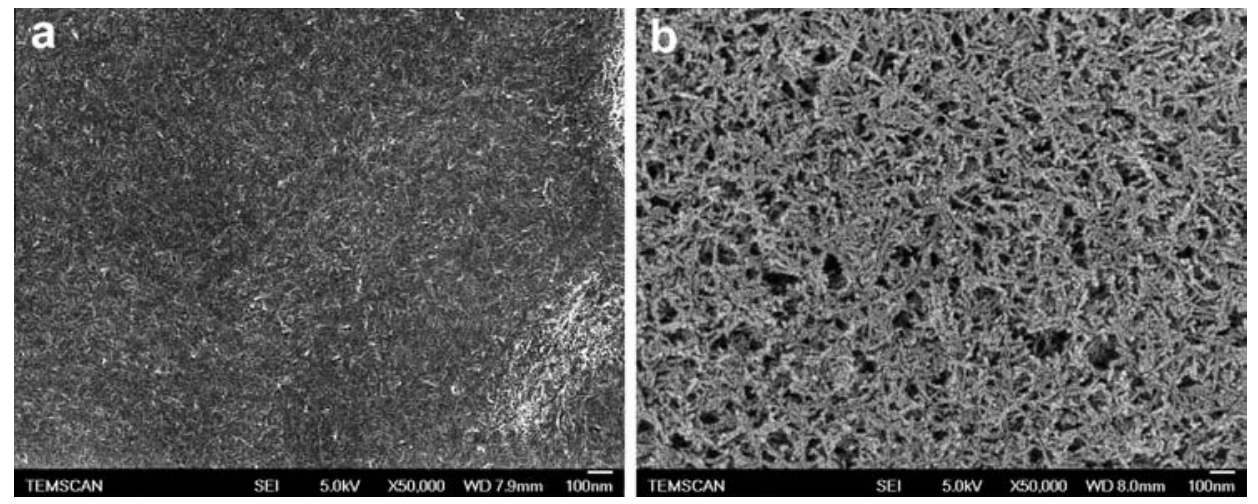

Fig. 7. SEM images of xerogels (after calcination at $500{ }^{\circ} \mathrm{C}$ for $2 \mathrm{~h}$ ) prepared from sols (a) without any additives (b) containing P123, $5 \% \mathrm{Mn}$ nitrate and $1 \% \mathrm{Cu}$ nitrate.

was shown that the critical micellar concentration $(\mathrm{CMC})$ of $\mathrm{EO} / \mathrm{PO}$ block copolymers was remarkably lowered on addition of inorganic salt [32]; this was accompanied by an increase in the core radius of micelle and the aggregation number. This was explained both by induced hydrophobicity in PPO block and dehydration of PEO moiety in PEO shell, making copolymer molecule more hydrophobic.

Finally it is also possible that addition of metal nitrate leads these hydrophobic micelles to aggregate into cubic or hexagonal structures [33]. This could explain why the maximum porosity was obtained for a P123 concentration twice above the maximum observed without addition of metal nitrates.

\section{Conclusions}

Addition of Pluronics ${ }^{\circledR}$ F127 and P123 in a boehmite hydrosol is a very convenient method to obtain, after drying and calcination, $\gamma$-alumina with large surface area and porosity. We showed that the effect of copolymer concentration on surface area and porosity was similar for both triblock copolymers, which seems to indicate that the amount of copolymer is more important than its structure.

When Mn nitrate was added to these sols the viscosity at low shear rate strongly increased and they gelled quickly, however an important shear thinning was observed and the gels returned to a sol state under shearing. Moreover a thixotropic behavior was observed. Addition of $\mathrm{Cu}$ or $\mathrm{Al}$ nitrate to these sols in low quantity has an opposite effect since the viscosity slightly decreased. It is only for metal concentrations above $2 \mathrm{wt} \%$ that we observed a behavior similar to Mn nitrate addition, though in a less extend.

Addition of a metal nitrate had a marked effect on the pore volume especially in the case of $\mathrm{Al}$ and $\mathrm{Cu}$. For xerogels prepared with Al nitrate at the maximum ( $4 \mathrm{wt} \%)$ a huge pore volume $\left(2.6 \mathrm{~cm}^{3}\right.$ $\mathrm{g}^{-1}$ ) was obtained. Though the pore volume increased only slightly (10\%) when Mn nitrate ( $5 \mathrm{wt} \%$ ) was added, a further addition of a small amount of $\mathrm{Cu}$ nitrate ( $1 \mathrm{wt} \%$ ) gave $\gamma$-alumina xerogels exhibiting both very large pore volume $\left(2.6 \mathrm{~cm}^{3} \mathrm{~g}^{-1}\right)$ and $\mathrm{S}_{\mathrm{BET}}$ $\left(500 \mathrm{~m}^{2} \mathrm{~g}^{-1}\right)$.

The pore size distribution (PSD) of xerogels prepared with Al nitrate was quite different that the PSD of xerogels obtained with $\mathrm{Cu}$ nitrate. Addition of Al nitrate created macroporosity giving a bimodal PSD with two very broad peaks centered at 25 and $40 \mathrm{~nm}$. This striking expansion of pore volume occurred with a P123 concentration of $17 \%$ although the maximum observed without addition of metal nitrates was for a twice as lower concentration. At this copolymer concentration only a minor expansion was found. Moreover this expansion was not observed with F127.

In summary, this work shows that, by addition of metal nitrates in a boehmite sol containing P123, it becomes possible to tune the pore volume of the $\gamma$-alumina xerogels in the range $0.3-2.6 \mathrm{~cm}^{3}$ $\mathrm{g}^{-1}$ and the median pore size in the range $5-40 \mathrm{~nm}$. All these materials have high surface areas in the range $300-500 \mathrm{~m}^{2} \mathrm{~g}^{-1}$.

\section{Acknowledgments}

This work was financially supported by DGCIS and the Regional Councils of Midi-Pyrénées and Aquitaine in the framework of SOFTAIR project.

\section{References}

[1] Phaik Yee Looi, Recent Pat. Corros. Sci. 1 (2011) 156-172.

[2] Q. Huo, D.I. Margolese, U. Ciesla, D.G. Demuth, P. Feng, T.E. Gier, P. Sieger, A. Firouzi, B.F. Chmelka, F. Schüth, G.D. Stucky, Chem. Mater. 6 (1994) 1176

[3] S.A. Bagshaw, T.J. Pinnavaia, Angew. Chem., Int. Ed. Engl. 35 (1996) 1102.

[4] P. Yang, D. Zhao, D.I. Margolese, B.F. Chmelka, G.D. Stucky, Nature 396 (1998) 152.

[5] F. Vaudry, S. Khodabandeh, M.E. Davis, Chem. Mater. 8 (1996) 1451

[6] H.Y. Zhu, J.D. Riches, J.C. Barry, Chem. Mater. 14 (2002) 2086-2093.

[7] Qian. Liu, Aiqin. Wang, Xuehai. Wang, Peng. Gao, Xiaodong. Wang, Tao. Zhang, Microporous Mesoporous Mater. 111 (2008) 323-333.

[8] Zhaorong. Zhang, Thomas. J. Pinnavaia, Langmuir 26 (2010) 10063-10067.

[9] Pasquale.F. Fulvio, Reno.I. Brosey, Mietek. Jaroniec, ACS Appl. Mater. Interfaces 2 (2010) 588-593.

[10] Rudina. Bleta, Pierre. Alphonse, Lisa. Pin, Marie. Gressier, Marie.-Joelle. Menu, J. Colloid Interface Sci. 367 (2012) 120-128.

[11] Paschalis. Alexandridis, Josef.F. Holzwarth, Macromolecules 27 (1994) 2414 2425.

[12] B.E. Yoldas, J. Mater. Sci. 10 (1975) 1856-1860.

[13] B.E. Yoldas, Am. Ceram. Soc. Bull. 54 (1975) 286-288.

[14] B.E. Yoldas, Am. Ceram. Soc. Bull. 54 (1975) 289-290.

[15] M. Wojdyr, J. Appl. Crystallogr. 43 (2010) 1126-1128

[16] A.L. Patterson, Phys. Rev. 56 (1939) 978-982.

[17] S. Brunauer, P. Hemmett, E. Teller, J. Am. Chem. Soc. 60 (1938) 309-319.

[18] N. Seaton, J. Walton, N. Quirke, Carbon 27 (1989) 853-861.

[19] J.I. Fukasawa, K. Tsujii, J. Colloid Interface Sci. 125 (1988) 155-161.

[20] M.J. Gieselmann, M.A. Anderson, J. Am. Ceram. Soc. 72 (1989) 980-985.

[21] K.C. Song, I.J. Chung, J. Non-Cryst. Solids 108 (1989) 37-44.

[22] R. Bleta, O. Jaubert, M. Gressier, M.J. Menu, J. Colloid Interface Sci. 363 (2011) 557-565.

[23] B. Derjaguin, L. Landau, Acta Physico Chemica URSS 14 (1941) 633.

[24] O.V. Shatalova, A.V. Krivandin, N.A. Aksenova, A.B. Solov'eva, Polym. Sci. Series A 50 (2008) 417-421.

[25] R.S. Zhou, R.L. Snyder, Sect. B: Struct. Sci. (1991) 617-630.

[26] K.S.W. Sing, D.H. Everett, R.A.W. Haul, L. Moscou, R.A. Pierotti, J. Rouquerol, T. Siemieniewska, Pure Appl. Chem. 57 (1985) 603-619.

[27] D. Chiche, C. Chizallet, O. Durupthy, C. Channeac, R. Revel, P. Raybaud, J.P. Jolivet, Phys. Chem. Chem. Phys. 11 (2009) 11310-11323.

[28] F. Mange, D. Fauchadour, L. Barre, L. Normand, L. Rouleau, Colloids Surf., A 155 (1999) 199-210.

[29] D. Fauchadour, F. Kolenda, L. Rouleau, L. Barre, L. Normand, Stud. Surf. Sci. Catal. 143 (2002) 453-461.

[30] C.R. Evanko, R.F. Delisio, D.A. Dzombak, J.W. Novak Jr., Colloids Surf. A 125 (1997) 95-107.

[31] R. Wood, D. Fornasiero, J. Ralston, Colloids Surf. 51 (1990) 389-403.

[32] N.J. Jain, V.K. Aswal, P.S. Goyal, P. Bahadur, Colloids Surf., A 173 (2000) 85-94.

[33] G. Wanka, H. Hoffmann, W. Ulbricht, Macromolecules 27 (1994) 4145-4159. 